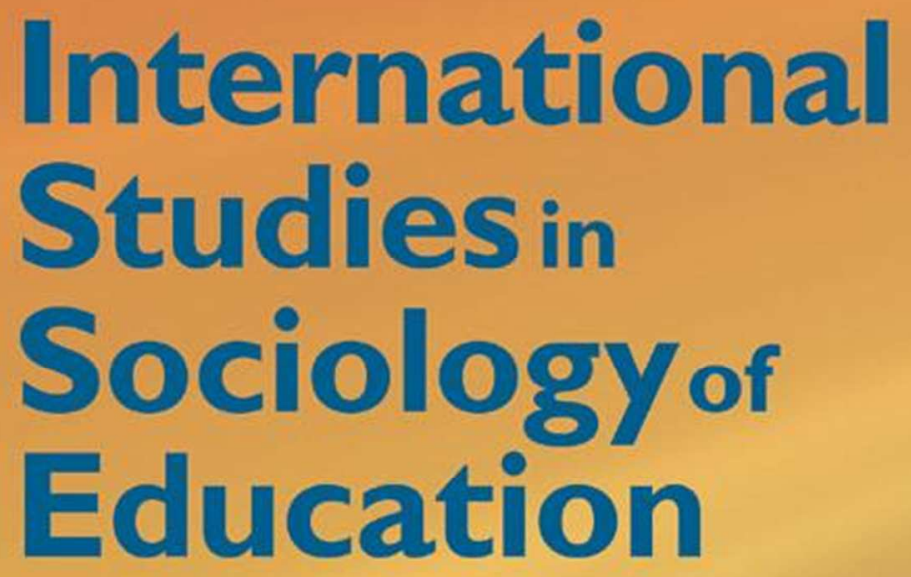

Routledge

Taylor \& Francis Group

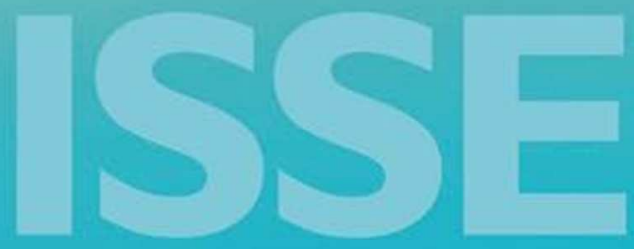




\section{Globalisation, cosmopolitanism and diaspora: What are the} implications for understanding citizenship?

\begin{tabular}{|r|l|}
\hline Journal: & International Studies in Sociology of Education \\
\hline Manuscript ID & RISS-2017-0030.R2 \\
\hline Manuscript Type: & Original Article \\
\hline Keywords: & citizenship, cosmopolitanism, globalisation, citizenship education policy \\
\hline Abstract: & $\begin{array}{l}\text { Contemporary global flows of people, ideas and capital have led to } \\
\text { profound changes in transnational interactions, affinities, forms of sociality } \\
\text { and understandings of citizenship. Traditional vocabularies of citizenship } \\
\text { struggle to cope with this rescaling of dimensions of citizenship in an } \\
\text { increasingly globalised world. In addition, educational policies and practices } \\
\text { remain primarily focused on normative, national conceptions of citizens, } \\
\text { thus overlooking the multiple, diverse and plural conceptualisations of } \\
\text { diverse young citizens in classrooms today. Arguing for a fresh approach } \\
\text { that applies 'cosmopolitan sociologies' (Beck, 2007) of education, in this } \\
\text { paper we propose a framework for understanding citizenship that centres } \\
\text { on spatial, relational and affective dimensions of citizenship. We review } \\
\text { recent research with young people highlighting the multiple ways in which } \\
\text { young people are constituted as citizens through a range of social, affective } \\
\text { and spatial affinities. The paper concludes by examining the implications of } \\
\text { this framework for educational policies and practices. }\end{array}$ \\
\hline \hline
\end{tabular}




\title{
Globalisation, cosmopolitanism and diaspora: What are the implications for understanding citizenship?
}

Paper submitted for the International Studies in Sociology of Education Special Issue: Migration, borders and education: International sociological inquiries

\begin{abstract}
Contemporary global flows of people, ideas and capital have led to profound changes in transnational interactions, affinities, forms of sociality and understandings of citizenship. Traditional vocabularies of citizenship struggle to cope with this rescaling of dimensions of citizenship in an increasingly globalised world. In addition, educational policies and practices remain primarily focused on normative, national conceptions of citizens, thus overlooking the multiple, diverse and plural conceptualisations of diverse young citizens in classrooms today. Arguing for a fresh approach that applies 'cosmopolitan sociologies' (Beck, 2007) of education, in this paper we propose a framework for understanding citizenship that centres on spatial, relational and affective dimensions of citizenship. We review recent research with young people highlighting the multiple ways in which young people are constituted as citizens through a range of social, affective and spatial affinities. The paper concludes by examining the implications of this framework for educational policies and practices.
\end{abstract}

Keywords: citizenship, cosmopolitanism, globalisation, citizenship education policy 


\section{Introduction: citizenship in a global and transnational context}

The mass movement of people across borders is not a new phenomenon. Forms of diaspora and mass migration, both voluntary and involuntary, have featured in almost every era of human civilisation. However, what has changed in recent times is the scale and the pace of such movements- and the parallel growth of global digital communication technologies which enable a much wider knowledge of such movements (Appadurai, 1996). Flows of people, ideas and information have a profound effect on society. As Bauman (2016) states, the population of many of the world's urban centres is nowadays a 'collection of diasporas' (p. 25) with a fluidity of membership which leads to the prospect of living permanently with variety and difference. The experience of migration and diaspora therefore confronts us on a global scale, necessitating humanitarian responses and triggering a fresh round of questions about our global responsibilities to others and what it means to be a citizen.

This rapid pace of migration and globalisation has significant implications for citizenship. As Staeheli (2011) argues, citizenship is now implicated in processes that represent a growing challenge to the nation-state and its traditional identifications, loyalties and enactments. In response, many citizenship scholars have argued for more global understandings of citizenship that are characterised by flexible and multiple notions of identity and connectedness beyond the nation-state (Isin, 2013; Isin \& Turner, 2007; Kallio \& Mitchell, 2016; Nyers \& Rygiel, 2012; Ronkainen, 2016). Some also suggest that globalising processes have led to a dis-embedding of social relations (Bauman, 2004) and a deterritorialisation of citizenship entitlements (Ong, 2005). As Kallio and Mitchell state, the nation-state no longer is the 'self evident loci of citizenship' (p. 259). Instead,

In their lived realities people identify with differently scaled and situated communities, build networks across cultural, political and physical borders, act in institutional and professional roles with manifold positions, form new publics and engender new commons, move between and resettle in different economic regions, and take action through various channels that may or may not be associated with formal structures (Kallio \& Mitchell, 2016, pp. 259-260).

However, as Isin and Turner (2007) remind us, although it is often assumed that globalisation creates a world in which citizenship loses its importance, recent events have confirmed the ongoing significance of the state in constituting the status, rights, and experiences of citizenship. Paradoxically therefore, despite the multiple mobilities of the globalised world, 'territorial belonging still matters to people' (Arp Fallov, Jørgensen, \& Knudsen, 2013, p. 468). Most people's lives still remain strongly rooted in local 
neighbourhoods and are lived through routinised patterns of everyday locality. Furthermore, at a time of growing mobility and transnational movements, the status of formal state citizenship has somewhat ironically increased in importance. As Castles (2005, p. 691) notes, 'the worst thing to be in a world of nation-states is a 'non-citizen'. In an increasingly mobile world, the 'right to mobility' (Turner, 2016, p. 681) and to cross borders is in fact one of the greatest assets held by individuals, one which relies on the ownership of a passport associated with a nation-state. The status of formal citizenship associated with a nation-state therefore holds enduring power even in a globalised and transnational world and means that we cannot completely divorce citizenship from notions of nationality.

In light of this rescaling of the dimensions of citizenship, in this paper we suggest that we need a fresh examination of the vocabularies and conceptual frameworks used to examine contemporary experiences and understandings of citizenship for those in particular who will inherit this changing state - the young. Drawing on recent research with young people across the world, we examine how static, territorial and status-bound notions of citizenship fail to capture young people's contemporary experiences as citizens, experiences which involve regular engagement in transnational, social and relational processes (Abu El-Haj, 2015; Kallio \& Mitchell, 2016; Nunn, McMichael, Gifford, \& Correa-Velez, 2016; Wood \& Black, 2017 , in print). However, rather than jettison the territoriality of the nation-state entirely, we argue for more spatially-agile, dynamic and flexible conceptions that acknowledge the multiscaled nature of citizenship and its constitution through a range of social and spatial affinities. To advance this further, we propose a fresh framework for understanding citizenship that centres on spatial, relational and affective dimensions, arguing that these three dimensions provide more flexible and dynamic ways of conceptualising and understanding citizenship today. This framework is not intended to be universally representative, nor to focus on any one specific geographic context, but to recognise and draw on some of the key themes and patterns which have emerged from recent research across a number of countries and that therefore contribute to a broad theory of citizenship with potential application to multiple contexts. In many ways, as a conceptual framework it seeks broadly to point to where to look for understandings of citizenship (in spatial, relational and affective ways) today, rather than how to look at these, which we leave open to researchers to interpret.

The paper begins with a critique of traditional notions of citizenship, and describes the emergence of some of the changing vocabularies of citizenship. It explores the triple-pronged spatial, relational and affective dimensions of citizenship which we propose in our 
framework. We then turn to the implications of this for educational policies and practices which remain primarily focused on normative, national conceptions of the 'good' citizen, thus overlooking the multiple, diverse and plural conceptualisations of diverse young citizens in classrooms today.

\section{Changing vocabularies of citizenship}

Traditionally, the grounds for inclusion as a citizen were based upon on notions of space, territoriality and boundaries associated with the nation-state. Marshall's (1950) historic analysis of citizenship defined this traditional notion of citizenship as the legal status and associated rights and duties of those who are full members of a community. However, as a result of increased transnational movements and flows and the intensification of social relations across borders, new affinities, loyalties, identities, animosities and hostilities have been generated (Bauman, 2004; Isin, 2008). These shifting configurations of time, space and mobility as a result of migration and globalisation have profound implications for how we conceptualise and think about citizenship, belonging and politics today (Kallio \& Mitchell, 2016; Youkhana, 2015). 'Vocabularies of citizenship' reflect different historical legacies and vary according to the social, political and cultural context within which they are conceived (Lister, Smith, Middleton, \& Cox, 2003). As Isin (2009) argues, we need new and more agile vocabularies that can adequately explain the emergence of new sites and scales of struggle, new rights, and new acts of citizenship. In the following we examine three ways that the vocabularies of citizenship have been re-examined, re-imagined and re-invoked in recent times.

First, there has been a sustained critique of traditional, normative notions of citizenship by feminists and other critics who argue that traditional claims for citizenship status have relied too heavily on public, quintessentially male and legal status-related templates. Such universalistic and normative approaches overlook the representation and participation of individuals and groups who fall outside the public gaze, such as those involved in unpaid domestic labour (Lister, 2003). This has the effect of marginalising the citizenship experiences of women, young people, children and many other less dominant cultural groups whose activities in society remain peripheral to mainstream economics and politics, thus rendering them invisible, or a type of 'semi' citizen. An approach which examines the politics of difference between groups in society presents opportunities for marginalised groups to be viewed as equal but different (Lister, 2007). Feminists have also drawn attention to the significance of small, everyday acts of politics within domestic and ordinary spaces where 
citizenship is actually practised, arguing that examining such mundane spaces gives insights into broader patterns and scales of power, politics and citizenship (Dyck, 2005).

A second critique questions the priority which traditional models have given to the legal status of citizenship, thus overlooking the practices which make citizens. Isin, for example, argues that we need to focus on those moments, when, regardless of status and substance, subjects constitute themselves as citizens, or (drawing on Arendt 1951), the acts of those to whom 'the right to have rights is due' (Arendt, 1951, p. 296). This understanding of citizenship is markedly distinct from that of Marshall, as it draws the focus away from the status of being a citizen to the acts and practices undertaken by citizen subjects and actors (Isin, 2008, 2009). Isin uses the example of the Sans-Papiers (literally, without papers), to illustrate this. In 1990, a group of undocumented migrants and refugees occupied a church in Paris, calling themselves the Sans-Papiers - and demanding the right to regularized status and to stay in France. Through these acts, Isin (2009) argues, they enacted themselves as activist citizens through their claims for justice and freedom of movement. They also therefore demonstrated transformational forms of citizenship acts and modes of being political, even whilst they held no citizenship status in France. He argues that citizenship formation is enacted through such a process of articulation of rights and shifts our attention from the actors to the acts of citizenship.

A third changing vocabulary of citizenship which has emerged in recent times relates to the sites and scales of citizenship. A number of theorists have argued that citizenship is layered: that is, it operates simultaneously at local, regional, nation-state and global levels, thus requiring more global, cosmopolitan and transnational conceptions (Heater, 1999; Osler \& Starkey, 2005). Beck (2007), for example, has proposed the notion of "cosmopolitanisation", or the "erosion of distinct boundaries dividing markets, states, civilizations, cultures, and not least of all the lifeworlds of different peoples" (p. 1). He suggests that this does not mean a borderless world, but rather one in which borders are more "permeable" and less distinct.

This line of argument has significance for how we think about space, time, identity and citizenship as it can loosen our fixation in boundaries and territories, and widen our analysis of interconnections, networks and relationships (Hörschelmann \& Refaie, 2014; Youkhana, 2015). It could also be argued, however, that the growing nationalism and securitisation of borders against both legal and illegal migration illustrates a reversion to the solidity of borders in ways that challenge Beck and similar arguments. As Turner (2016) argues, "the 
relationship between territory and rights has become the critical issue in the sociology of citizenship" (p. 681). Kallio and Mitchell (2016) have also pointed out two potential dangers of a transnational theorisation of citizenship that overlooks the enduring significance of the state at a time of unprecedented migration: first, it runs the risk of losing the context of citizenship; and, second, it runs the risk of losing the subject of citizenship. To avoid this, they propose to respatialize citizenship and denationalize it conceptually, two approaches which we find helpful in this paper.

These three aspects of changing citizenship vocabularies change our conception of the political as well as of citizenship. In turn, as researchers, our methodological approaches are similarly challenged by such conceptual understandings. Beck and Sznaider (2006) suggest that the current global transformation of modernity calls for a re-thinking of the humanities and social sciences. In particular, they argue for a transformation of positions and conceptual tools which takes cosmopolitanism seriously as a research agenda in light of the many social relations and interactions which extend within and beyond the nation-state. This requires, they argue, a critique of methodological nationalism which assumes that society is equated with national society, and a reconceptualization of methodological cosmopolitanism that draws on new forms of conceptual and empirical analysis to recognise the interconnected nature of sociality (Beck \& Sznaider, 2006) and 'jumble together the native with the foreign' (Beck, 2007, p. 287).

Such scholarship does not argue for the demise of the nation-state, or for the insignificance of national rules, practices and traditions. This argument would be difficult to make at a time when nation-states are increasingly reinscribing rules, practices and traditions in relation to citizenship, either by restricting or excluding those whose citizenship identities are seen to be a risk to the cohesiveness and safety of the state, or else by passing legislation to revoke or limit the scope of existing citizenship rights in the name of that state. What recent scholarship does illustrate, however, is that we need much more flexible sociological tools to map new social realities, including space and time. In the following section of this paper, we attempt to contribute to a more cosmopolitan sociology by presenting a framework for citizenship which is fluid, dynamic, historically grounded and geographically responsive (Isin, 2009). We propose three dimensions to this emergent type of citizenship which requires deeper spatial, relational and affective understandings. We begin with the first of these dimensions - space. 


\section{The spatial geographies of young people's citizenship}

When it comes to young people's experience as citizen actors in an increasingly globalised world, space matters. As we note in the earlier sections of this chapter, citizenship has never been geographically neutral. Whether as a notion, an ideal or a legal status, it has always by definition been linked to the specific political and social geography of the nation-state. It has also been linked to specific physical geographies: as Desforges (2005) and his colleagues argue, it has always been 'formed through scalar configuration and engagement with place' (p.444).

At the same time, as Staeheli (2011) argues, 'the borders of citizenship are everywhere - at the physical boundary of national territories, in communities, in political practices and policies, in social norms, embodied in individuals' ( p.395). This is increasingly true for young people. Increasingly mobile populations - whether forced by migration or chosen enhance cultural flows and the expansion of digital technologies and social media have led to multiple sites of identity for young people today. This means that, as we have discussed above, fixed and territorial definitions of citizenship no longer adequately capture the complexity of young people's citizenship experience. Antonsich (2010) has mounted a rather impassioned argument that contemporary human geographies and their emphasis on social, political and economic forces are overlooking what he calls 'the personal, intimate, existential relation between the individual and her/his place' (p.129). This doesn't mean we can simply replace our spatial models from the national with the global, nor replicate traditional container-like models of space. Instead, spatially-sensitive approaches to understanding young people's citizenship require much more dynamic and relational understandings of space that encompass citizenship identities (Hörschelmann \& Refaie, 2014).

Recent scholarship in youth studies has shown a growing attentiveness to space and the ways in which young people experience and enact their citizenship (e.g. Cuervo \& Wyn, 2014; Cuervo \& Wyn, 2017; Farrugia \& Wood, 2017; Harris, 2015). These contributions recognise the power and role of place attachment for young people's feelings and experiences of citizenship and belonging, frequently focusing on the role of local as a key site of these feelings and experiences. As Harris and Wyn (2009) observe, it is within the 'microterritories of the local that young people may form their strongest sense of belonging and citizenship' (p. 327). 
A number of recent research contributions illustrate this enduring importance of local spaces and places for young people's citizenship identification and acts. For example, Goodwin and Young (2013) describe the citizen acts of young people within their social housing neighbourhoods in urban Sydney, acts that arise out of concern about how issues such as violence and homelessness were affecting their community. Similarly, Roose and Harris (2015) outline the ways in which young Muslim people in Australia draw on Islamic practices and values to enact good citizenship within the 'multicultural spaces of their everyday lives', spaces which include the workplace and the local neighbourhood (p. 474). There are also discussions in the literature that recognise the influence of local spaces and places in forming or reshaping young people's citizenship dispositions. Nagel and Staeheli (2016) describe the efforts of a western-funded NGOs in post-conflict Lebanon to cultivate positive citizenship values and social interactions by engaging young people in environmentalism. Activities such as camping, scouting, eco-tourism and local environmental preservation initiatives have been used, as they have in other post-conflict settings, to promote non-sectarian cooperation and cultivate 'new social norms' based on ideas of 'empowerment, individual responsibility, and active citizenship' (Nagel \& Staeheli, 2016, p.248).

Recognising the centrality of physical geography in young people's citizenship is also central to understanding the experiences of some of the most disenfranchised or insecure. For the vast numbers of young people forced to be 'out of place' in search of economic and social security in locations across the globe, formal nation-state citizenship is far from an outdated notion: it is 'a critical and widely shared goal' (Nunn et al., 2016, p. 382). For some of these young people, enacting citizenship is a complex, juggling act. Even while they are increasingly engaged in efforts to make a life in a new place and to integrate themselves into the life of their new host nations, they are 'engaging in transnational processes that include maintaining social connections via telephone and other information and communication technologies, return visits, remittances and engagement with homeland politics' (Nunn et al., 2016, p. 388). Even where young people have been legally and formally accepted by their new nation-state, many continue to live as citizens 'across multiple real and imagined national terrains' (Abu El-Haj, Bonet, Demerath, \& Schultz, 2011, p. 31), 'constructing “glocal" lives' (p.56) through everyday engagements and interactions 'within and across the borders of nation-states' (p. 54). Staeheli has beautifully summed up the geography of young people's citizenship in a globalised world and the complexities that attend it: 
There are no stable, fixed answers to the questions of where citizenship and citizen-subjects are located. They are [...] seemingly everywhere (2011, p. 399).

This draws attention to the inseparability of social interactions and relationship to the experience of citizenship - as we discuss in this second dimension.

\section{Citizenship and relationships}

Young people's citizenship is constituted at the intersection of relationships with others. It is not carved out in an isolated endeavour, but is lived, practised and shaped in the context of others. Citizenship is defined and experienced above all as 'a set of relationships by which membership is constructed through physical and metaphorical boundaries and in the sites and practices that give it meaning' (Staeheli, 2011, p.394). These relationships are both inclusionary and exclusionary and form landscapes of both belonging and exclusion for young people that are highly marked by race, gender, and class (Wood, 2016). The effects of globalisation have only accentuated this, creating what Staeheli (2016) terms 'a new spatiality of citizenship' (p.63) with inescapably relational dimensions. This may be particularly true for young people, especially in instances where their citizenship is precarious or poorly recognised by the adults and institutions of the local places in which they live and learn.

A relational perspective can enable us to understand the intersection between the formal political sphere of citizenship and young people's interpersonal relationships and connections (Hörschelmann \& Refaie, 2014), but it can also shed light on the more immediate and localised experiences that make up citizenship. For many young people, the experience of feeling like a citizen, with the recognition and belonging that this entails, is contingent on being made welcome within 'a community of membership' (Anthias, 2006, p. 21). It is contingent on having access to those 'social relationships that provide a life anchor, a sense of personal physical and symbolic location' (Cuervo \& Wyn, 2014, p.7). For many young people, of course, this welcome may not be forthcoming. Introducing their special edition on citizenship and affect in the midst of some of the events of 2016, which included Brexit and the attack in Nice with its attendant widespread rejection of immigration and immigrants, Di Gregorio and Merolli (2016) remind us that 'citizenship has a central role to play in any understanding of the conditions under which one can participate or be excluded from political life' (p.934). This point leads us to our third dimension of citizenship - that of the feeling or affective component of citizenship. 


\section{Affective citizenship}

A final dimension of young people's citizenship, and one that is almost inseparable from the two dimensions we discuss earlier, is its affective nature. As Boudreau (2015) and her colleagues note, citizenship implies not only a legal but an 'affective link to the state and the nation' (p.337). Yet, the affective aspects of citizenship have long been neglected. This is beginning to change now with evidence of scholarship in this area (see Di Gregorio \& Merolli, 2016), a scholarship which recognises that citizenship and the policies and practices that attend it are often characterised by a combination of anxiety, desire and other feelings. In particular, feelings of belonging or not belonging are inseparable from the experience of both being and feeling a citizen. This highlights the inseparable inclusionary and exclusionary nature of citizenship (Isin, 2008), that as discussed above, is strongly spatial and relational. As Yuval-Davis (2006) notes, the politics of belonging involve 'the dirty work of boundary maintenance' (pg. 204).

A number of studies have captured the essential complexity of many young people's affective citizenship experiences in the social spaces created by globalisation. These experiences frequently include a rejection of the discourses that would exclude them from recognition as citizens and a high degree of creativity in forging or redefining their relationship and place within dominant social structures. They also reflect an engagement or entrapment in the desire that frequently attends citizenship (Fortier, 2016). One example comes from Schmitt's (2010) account of the efforts of secondary school-aged young migrants in Germany to create 'their own brands' of citizenship and belonging (p.174) in the face of a strong political and cultural environment that constructs them as "other". Another comes from Boudreau and her colleagues' (2015) depiction of young activists in Montreal, and the ways in which they both 'play with fear' and 'generate fear' through "alternative" citizenship practices, such as being a graffiti artist or climbing buildings for Greenpeace, which are physically, legally and/or emotionally risky (p.335). These studies highlight the inseparable nature of emotions in constructing and shaping young citizens dispositions and actions.

It could be said that, in western democracies at least, the citizenship of all young people is subject to affective discourses. These frequently depict them as democratically disengaged and apathetic, promoting and perpetuating a construction of the 'at risk' young citizen that has flourished since the resurgence in the late 1980s of policy concern about the future of the 
democratic system (see Black, 2011). Educational responses to this concern has seen the widespread development of policies, curricula and programs designed to engage young people as citizens, strategies that have an affective underpinning but that often overlook or underestimate the affective engagement that many young people already have with democratic life. Cammaerts and his colleagues (2014) have described the strong desire of young people across the United Kingdom, France, Spain, Austria, Finland and Hungary to participate as citizens, albeit on their own terms, a finding that has also been borne out in recent studies of young Australians' democratic engagement (Walsh \& Black, 2017). In Russia, young people's citizenship has been the subject of 'a continual process of educational interventions' (Krupets, Morris, Nartova, Omelchenko, \& Sabirova, 2016, p.8) that do little to recognise the strong affective attachment which young people already have to their country and to the idea of citizenship. This heralds a cautionary note to accompany the growing levels of promotion of young people's active citizenship and volunteering through schools and society which hold the potential for emotional manipulation and coercion - in the name of creating 'good' citizens (Wood, 2015).

In sum, if we put together these three dimensions of contemporary citizenship, we have an intersecting framework for understanding citizenship which is remarkably different than Marshall's (1950) seminal work in the 1950s. Rather than only relying only on legal status, rights and responsibilities, this framework recognises the intersectional nature of citizenship and affect, and the socio-spatial significance of relationships in shaping citizenship at multiscalar levels (Youkhana, 2015). Citizenship necessarily happens at the intersection of interactions with others (Isin, 2008), and through spatially-dynamic practices. This does not mean we do away with legal and state-based notions of citizenship; rather, that it exposes many deeper layers of understandings about what it means to live citizenship and be a citizen. These understandings of citizenship have significant implications for educational policy and practice, especially at a time of mass migration, and in the final section of this paper we turn to these.

\section{Implications for educational policy and practice}

The ongoing concern which we see across western democracies about the viability of the democratic system invariably centres on one subject: the young citizen. Almost as invariably, it is met with one policy response: a call for more - or else more effective - citizenship education (Bessant, Farthing, \& Watts, 2016). The clamour of such calls has become louder 
in many places in light of far-right political attacks on immigration and the status of refugees globally, particularly in countries of the Global North. The implications of diaspora and growing migration are also increasingly significant for education policy given the growing cultural and religious diversity represented now in many classrooms of the Global North. Yet, the nature of citizenship education policy, and the structures of schooling mean that there are significant challenges to promoting more flexible and dynamic understandings of citizenship.

One of the chief concerns attending citizenship education policies and practices is that they remain primarily focused on normative, national conceptions of the good or desirable citizen that preclude more diverse and pluralised conceptualisations. In light of the theoretical framework which we have proposed in this paper, we suggest that education policy needs to promote a more flexible, responsive and expansive understanding of citizenship that better reflects the diversity of the students in our classrooms. In addition, education policy needs to more concertedly recognises that young people today grow up with more-than-local politics (Mitchell \& Parker, 2008), but are still heavily influenced by the policies and practices associated with their nations and communities. For the contemporary nation-state, the desirable young citizen is one who has been educated to maintain 'endless self-scrutiny, an individualized focus on one's personal development over and above the well-being of the collective, and the capacity to continually renegotiate one's skills and identity in light of the demands of global capitalism' (Kennelly, 2009, p. 133). This sounds much like the recipe for a universal neoliberal citizen subject, but when implemented in specific places and in the context of specific political, social and historical relationships, it may exclude large numbers of young people from identifying themselves as desirable citizens.

While schools are key sites for the teaching and the formation of citizenship, they are also highly problematic places in which to be citizens. As Staeheli (2011) notes, 'the school is a site in which key concepts such as equality, democracy, history, justice, belonging, and citizenship are contested' (p. 395). In Spain, for example, Rios-Roja (2011) has described the efforts of young immigrants in Barcelona to negotiate a sense of citizenship in the face of 'interventionist educational policies and academic discourses concerned with facilitating immigrants' integration' (p.65). Writing from Canada, Kennelly (2009) observes the way in which schools perpetuate the discursive message that 'the good (real) citizen in Canada is white' (p.138), a message which immediately excludes and precludes indigenous and culturally diverse young people. In Australia, Black (2015) has described the way in which conventional citizenship education curricula fail to reflect the experiences and identities of 
culturally diverse young people and those being schooled in low socioeconomic communities. The feeling of exclusion such practices render have profound implications for citizen behaviours and dispositions both now and in the future. A deeper 'methodological cosmopolitanism' understanding of citizenship takes into account the multiple, transnational and diverse experiences of all citizens and the affective implications of these experiences rather than assuming a linear process of assimilation or integration.

The normative conception of citizenship which characterises much education policy and practice also has further effects: it reflects and reproduces an 'abstract notion' of citizenship and belonging (Kennelly \& Dillabough, 2008, p.494). This only poorly captures the complexity and specificity of young people's citizenship feelings and experiences in the particular globalised places in which they live and in relation to others, both in and beyond those places. Following Schmitt (2010), we argue that education needs to better recognise citizenship 'as a situated achievement in specific settings' and to recognise young people 'as societal actors rather than objects of political and educational projects' (pp.174-175). We suggest that inadequate understandings of citizenship produce poor quality education policies - including normative and territorial-linked conceptions of citizenship - that overlook the diverse and spatially complex experiences of young citizens today.

This requires a number of shifts in the nature of education policy and practice, shifts which more cosmopolitan sociologies of education can help achieve. Firstly, new ways of understanding are needed about how education policy making is shaped at the intersection of national and global relations, not just within national borders (Beck \& Sznaider, 2006). Rizvi and Lingard (2010) argue that older theoretical and methodological tools are no longer sufficient to understand a world that is increasingly networked and shaped by transnational forces and connections to the extent that there is now a global policy educational field. Along with others, they suggest that the realm of policy work has shifted from a primary focus on the nation state to a much more globalised field, arguing that 'the educational policy field today is multi-layered, stretching from the local to the global' (Lingard, Rawolle, \& Taylor, 2005 , p. 761) in a way that explains the multi-perspectival, boundary-transcending nature of relations of global interdependence today (Beck \& Sznaider, 2006). Cosmopolitan understanding of citizenship education policy therefore need to recognise the pervading influence of global policy actors in shaping national policy and conceptions of identity and the inadequacy of global and normative notions of the 'good' citizen. They also need to 
attend to constructions of solidarity and exclusion that occur at different sites and scales and how these emerge to shape citizen experiences today.

Following on from this, the practices of education need to reflect a better understanding of the multidimensional and multi-spatial nature of young people's citizenship and its relationship and response to the complex dynamics of globalisation. Osler and Starkey (2005) suggest that citizenship education needs to more explicitly recognise issues of diversity by working toward creating citizens of a world community based on common human values. Any educational strategy that seeks to promote and support young people's citizenship should 'affirm the status of young people as moral and political agents' (Bessant et al., 2016, p.284), not just locally, but also globally. Educators and policymakers must do more to understand what democracy 'actually means' to young people (Nieuwelink, Dekker, Geijsel, \& ten Dam, 2016, p.990, our italics). As part of this, they must do more to recognise both the 'situated and relational experiences' that characterise the young lives in which they are seeking to intervene (Black, 2012, p.226) and the multi-scaled nature of young people's citizenship today.

With these things in mind, we propose that more cosmopolitan policies, methodologies and sociologies of education could support a fresh framework for understanding young people's citizenship that centres on the lived spatial, relational and affective dimensions of experiences being young citizens today. Dynamic and flexible conceptions of citizenship would acknowledge the multiple ways in which young people are constituted as citizens through a range of social and spatial affinities. They would better recognise the emotional or affective investment which many young people have in their citizenship and in the democratic process, an investment that is routinely overlooked by the persistent depiction within the policy and public sphere of young people as democratically flawed and problematic. The development of new 'cosmopolitan sociologies' (Beck, 2007) of education understand the diversity of young people's existing citizenship affiliations. They would also create a more historically grounded and geographically responsive environment within the school for the recognition and enactment of those affiliations. 


\section{References}

Abu El-Haj, T. R. (2015). Belonging in troubling times: Considerations from the vantage point of Arab American immigrant youth. In J. Wyn \& H. Cahill (Eds.), Handbook of children and youth studies (pp. 433-445). Singapore: Springer.

Abu El-Haj, T. R., Bonet, S. W., Demerath, P., \& Schultz, K. (2011). Education, Citizenship, and the Politics of Belonging: Youth From Muslim Transnational Communities and the "War on Terror". Review of Research in Education, 35, 29-59.

Antonsich, M. (2010). Meanings of place and aspects of the Self: an interdisciplinary and empirical account. GeoJournal, 75(1), 119-132.

Appadurai, A. (1996). Modernity at large. Minneapolis: University of Minnesota Press.

Arendt, H. (1951). The origins of totalitarianism. NY: Harcourt Brace Jovanovich.

Arp Fallov, M., Jørgensen, A., \& Knudsen, L. B. (2013). Mobile Forms of Belonging. Mobilities, 8(4), 467-486. doi:10.1080/17450101.2013.769722

Bauman, Z. (2004). Liquid sociality. In N. Gane (Ed.), The future of social theory (pp. 17-46). London: Continuum.

Bauman, Z. (2016). Living in an age of migration and diasporas. In P. Ahponen, P. Harinen, \& V.-S. Haverinen (Eds.), Dislocations of civic and cultural borderlines (pp. 21-32). Switzerland: Springer.

Beck, U. (2007). The cosmopolitan condition: Why methodological nationalism fails. Theory, culture \& society, 24(7-8), 286-290. doi:10.1177/02632764070240072505

Beck, U. (2007). A new cosmopolitanism is in the air. Literaturen, November 2007.

Beck, U., \& Sznaider, N. (2006). Unpacking cosmopolitanism for the social sciences: a research agenda. The British Journal of Sociology, 61, 381-403. doi:10.1111/j.14684446.2009.01250.x

Bessant, J., Farthing, R., \& Watts, R. (2016). Co-designing a civics curriculum: young people, democratic deficit and political renewal in the EU. Journal of Curriculum Studies, 48(2), 271-289. doi: 10.1080/00220272.2015.1018329

Black, R. (2011). Student participation and disadvantage: limitations in policy and practice. Journal of Youth Studies, 14(4), 463-474. doi: 10.1080/13676261.2010.533756

Black, R. (2012). Educating the reflexive citizen: making a difference or entrenching difference? PhD Thesis. The University of Melbourne, Melbourne. Retrieved from http://repository.unimelb.edu.au/10187/17319

Black, R. (2015). Between policy and a hard pedagogical place: the emotional geographies of teaching for citizenship in low socioeconomic schools. Pedagogy, Culture \& Society, 23(3), 369-388. doi: 10.1080/14681366.2014.994664

Boudreau, J.-A., Liguori, M., \& Séguin-Manegre, M. (2015). Fear and youth citizenship practices: insights from Montreal. Citizenship Studies, 19(3-4), 335-352. doi: 10.1080/13621025.2015.1006177

Cammaerts, B., Bruter, M., Banaji, S., Harrison, S., \& Anstead, N. (2014). The Myth of Youth Apathy: Young Europeans' Critical Attitudes Toward Democratic Life. American Behavioral Scientist, 58(5), 645-664. doi: 10.1177/0002764213515992

Castles, S. (2005). Hierarchical Citizenship in a World of Unequal Nation-States. PS: Political Science and Politics, 38(4), 689-692.

Cuervo, H., \& Wyn, J. (2014). Reflections on the use of spatial and relational metaphors in youth studies. Journal of Youth Studies, 17(7), 901-915. doi: 10.1080/13676261.2013.878796

Cuervo, H., \& Wyn, J. (2017). A Longitudinal Analysis of Belonging: Temporal, Performative and Relational Practices by Young People in Rural Australia. Young, 25(3), 1-16. doi: $10.1177 / 1103308816669463$

Desforges, L., Jones, R., \& Woods, M. (2005). New Geographies of Citizenship. Citizenship Studies, 9(5), 439-451. doi: 10.1080/13621020500301213 
Di Gregorio, M., \& Merolli, J. L. (2016). Introduction: affective citizenship and the politics of identity, control, resistance. Citizenship Studies, 20(8), 933-942. doi: $10.1080 / 13621025.2016 .1229193$

Dyck, I. (2005). Feminist geography, the 'everyday', and local-global relations: Hidden spaces of place-making. The Canadian Geographer, 49(3), 233-243.

Farrugia, D., \& Wood, B. E. (2017).Youth and Spatiality: Towards interdisciplinarity in youth studies. Young, 25(3), 209-218. doi:10.1177/1103308817712036

Fortier, A.-M. (2016). The psychic life of policy: Desire, anxiety and 'citizenisation' in Britain. Critical Social Policy, 37(1), 3-21. doi: 10.1177/0261018316655934

Goodwin, S., \& Young, A. (2013). Ensuring Children and Young People Have a Voice in Neighbourhood Community Development. Australian Social Work, 66(3), 344-357.

Harris, A. (2015). At Home/Out of Place: Young People's Multicultural Belongings. In F. Mansouri (Ed.), Cultural, Religious and Political Contestations: The Multicultural Challenge (pp. 155-167). Heidelberg: Springer International Publishing.

Harris, A., \& Wyn, J. (2009). Young people's politics and the micro-territories of the local. Australian Journal of Political Science, 44(2), 327-344.

Heater, D. (1999). What is citizenship? Malden, MS: Polity Press.

Hörschelmann, K., \& Refaie, E. E. (2014). Transnational citizenship, dissent and the political geographies of youth. Transactions of the Institute of British Geographers, 39(3), 444456. doi: $10.1111 /$ tran. 12033

Isin, E. (2008). Theorising acts of citizenship. In E. Isin \& G. M. Nielsen (Eds.), Acts of citizenship (pp. 15-43). London/NY: Palgrave Macmillan.

Isin, E. (2009). Citizenship in flux: The figure of the activist citizen. Subjectivity, 29(1), 367-388. doi:doi:10.1057/sub.2009.25

Isin, E. F. (Ed.). (2013). Democracy, Citizenship and the Global City. New York: Routledge.Isin, E., \& Turner, B. (2007). Investigating citizenship: An agenda for citizenship studies. Citizenship studies, 11(1), 5-17.

Kallio, K. P., \& Mitchell, K. (2016). Introduction to the special issue on transnational lived citizenship. Global Networks, 259-267. doi:10.1111/glob.12113

Kennelly, J. (2009). Good citizen/bad activist: The cultural role of the state in youth activism. The Review of Education, Pedagogy, and Cultural Studies, 31(2-3), 127-149.

Kennelly, J., \& Dillabough, J. A. (2008). Young people mobilizing the language of citizenship: struggles for classification and new meaning in an uncertain world. British Journal of Sociology of Education, 29(5), 493-508.

Krupets, Y., Morris, J., Nartova, N., Omelchenko, E., \& Sabirova, G. (2016). Imagining young adults' citizenship in Russia: from fatalism to affective ideas of belonging. Journal of Youth Studies, 1-16.

Lingard, B., Rawolle, S., \& Taylor, S. (2005). Globalizing policy sociology in education: working with Bourdieu. Journal of Education Policy, 20(6), 759-777. doi: $10.1080 / 02680930500238945$

Lister, R. (2003). Citizenship: Feminist perspectives (2nd ed.). London: Macmillan.

Lister, R. (2007). Inclusive citizenship: Realising the potential. Citizenship studies, 11(1), 49-61.

Lister, R., Smith, N., Middleton, S., \& Cox, L. (2003). Young people talk about citizenship: Empirical perspectives on theoretical and political debates. Citizenship studies, 7(2), 235253.

Marshall, T. H. (1950). Citizenship and social class. Cambridge: Cambridge University Press.

Nagel, C., \& Staeheli, L. (2016). Nature, environmentalism, and the politics of citizenship in post-civil war Lebanon. Cultural Geographies, 23(2), 247-263. doi: $10.1177 / 1474474015572304$

Nieuwelink, H., Dekker, P., Geijsel, F., \& ten Dam, G. (2016). 'Democracy always comes first': adolescents' views on decision-making in everyday life and political democracy. Journal of Youth Studies, 19(7), 990-1006. doi: 10.1080/13676261.2015.1136053 
Nunn, C., McMichael, C., Gifford, S. M., \& Correa-Velez, I. (2016). Mobility and security: the perceived benefits of citizenship for resettled young people from refugee backgrounds. Journal of Ethnic \& Migration Studies, 42(3), 382-399. doi: 10.1080/1369183X.2015.1086633

Nyers, P., \& Rygiel, K. (2012). Citizenship, migrant status and the politics of movement. London: Routledge.

Ong, A. (2005). (Re)Articulations of Citizenship. PS: Political Science and Politics, 38(4), $697-$ 699.

Osler, A., \& Starkey, H. (2005). Changing citizenship: Democracy and inclusion in education. Maidenhead: Open University Press.

Osler, A., \& Starkey, H. (2003). Learning for cosmopolitan citizenship: Theoretical debates and young people's experiences. Educational Review, 55(3), 243-254.

Ríos-Rojas, A. (2011). Beyond Delinquent Citizenships: Immigrant Youth's (Re)Visions of Citizenship and Belonging in a Globalized World. Harvard Educational Review, 81(1), 64-94.

Rizvi, F., \& Lingard, B. (2010). Globalizing education policy. London/NY: Routledge.

Ronkainen, J. (2016). Contents of citizenship? Multiple citizens' orientations towards nationality and different forms of citizenship. In P. Ahponen, P. Harinen \& V.-S. Haverinen (Eds.), Dislocations of civic cultural borderlines (pp. 33-56). Switzerland: Springer.

Roose, J. M., \& Harris, A. (2015). Muslim citizenship in everyday Australian civic spaces. Journal of intercultural studies, 36(4), 468-486.

Schmitt, I. (2010). 'Normally I should belong to the others': Young people's gendered transcultural competences in creating belonging in Germany and Canada. Childhood, 17(2), 163-180.

Staeheli, L. A. (2011). Political geography: where's citizenship? Progress in Human Geography, 35(3), 393-400. doi: http://dx.doi.org/10.1177/0309132510370671

Staeheli, L. A. (2016). Globalization and the scales of citizenship. Geography Research Forum, $19,60-77$.

Turner, B. S. (2016). We are all denizens now: on the erosion of citizenship. Citizenship studies, 20(6-7), 679-692. doi:10.1080/13621025.2016.1191432

Walsh, L. L., \& Black, R. (2017). Rethinking Youth Citizenship after the Age of Entitlement. London: Bloomsbury.

Wood, B. E. (2015). Freedom or coercion? Citizenship education policies and the politics of affect. In P. Kraftl \& M. Blazek (Eds.), Children's Emotions in Policy and Practice: Mapping and Making Spaces of Childhood (pp. 259-273). UK: Palgrave MacMillan.

Wood, B. E. (2016). Excluded citizens? Participatory research with young people from a 'failing' school community. Children's Geographies, 14(3), 310-324. doi:10.1080/14733285.2015.1043515

Wood, B. E., \& Black, R. (in print). Spatial, relational and affective understandings of citizenship and belonging for young people today: Towards a new conceptual framework. In C. Halse (Ed.), Interrogating belonging among young people in schooling (pp. 199-226). Basingstoke: Palgrave MacMillan.

Youkhana, E. (2015). A conceptual shift in studies of belonging and the politics of belonging. Social Inclusion, 3(4). doi:http://dx.doi.org/10.17645/si.v3i4.150

Yuval-Davis, N. (2006). Belonging and the politics of belonging. Patterns of Prejudice, 40(3), 197-214. 